Annals of Glaciology $3 \quad 1982$

(C) International Glaciological Society

\title{
THE RADIATION BUDGET AT MIZUHO STATION,
}

\section{ANTARCTICA, 1979}

\author{
by
}

Takashi Yamanouchi, Makoto Wada, Shinji Mae, Sadao Kawaguchi and Kou Kusunoki

(National Institute of Polar Research, 9-10, Kaga-1-chome, Itabashi-ku, Tokyo 173, Japan)

\section{ABSTRACT}

Radiation budget measurements were made at Mizuho station $\left(70^{\circ} 42^{\prime} \mathrm{S}, 44^{\circ} 20^{\prime} \mathrm{E}, 2230 \mathrm{~m}\right.$ a.s.1.), East Antarctica, in 1979, within the framework of the Japanese POLEX-South programme. Global, and reflected short-wave and downward and upward long-wave radiation fluxes were measured at the snow surface and at the top of a $30 \mathrm{~m}$ tower. Direct solar radiation was al so measured at the snow surface.

Seasonal variations of net radiation and net short-wave and net long-wave radiation are presented. Daily variation of net radiation is al so presented with the daily value of meteorological elements. The monthly amounts of net radiation in winter months had very large negative values of about $-80 \mathrm{MJ} \mathrm{m}^{-2}$ month $^{-1}$. $\left(-2 k l y\right.$ month $\left.^{-1}\right)$. Daily totals of net radiation for clear skies were negative even in summer, and were always smaller than those for cloudy skies. Monthly amounts of net radiation in summer months (about $-1 \mathrm{MJ} \mathrm{m} \mathrm{m}^{-2}$ month $^{-1}$ in December) were the smallest among the several Antarctic stations compared, and whether the balance was negative or positive depended on the ratio of clear and cloudy days. Comparison of seasona) variations of radiation components was made and the dominant cause of the radiation balance was discussed.

\section{INTRODUCTION}

In 1970 the Japanese Antarctic Research Expedition (JARE) established Mizuho station at $70^{\circ} 42^{\prime} \mathrm{S}$, $44^{\circ} 20^{\prime} \mathrm{E}(2230 \mathrm{~m}$ a.s.1.) to carry out research on meteorology, glaciology, and upper atmosphere physics (Fig.1). Continuous katabatic winds of 10 to $12 \mathrm{~m} \mathrm{~s}^{-1}$, causing drifting snow, are characteristic of the station.

Actively participating in the Polar Experiment (POLEX) as a sub-programme of the Global Atmospheric Research Program (GARP), the implementation of the Japanese POLEX programme in the Antarctic (POLEXSouth) was planned to be carried out at Mizuho and Syowa stations $\left(69^{\circ} 00^{\prime} \mathrm{S}, 39^{\circ} 35^{\prime} \mathrm{E}\right)$ from 1979 to 1982 by JARE (Kusunoki 1981). The main research subjects are: radiation budget, air-sea-ice interaction, and atmospheric circulation in the Antarctic. At Mizuho station, many thermometers, anemometers, and wind vanes were installed on a $30 \mathrm{~m}$ tower to investigate the surface boundary layer. Six radiometers were also installed on the top of the tower to study the effect of drifting snow upon radiation, in parallel with 12 radiometers on the snow surface. Details of the installation and performance of the measurement system were reported by Mae and others (1981).

This paper presents some results of radiation

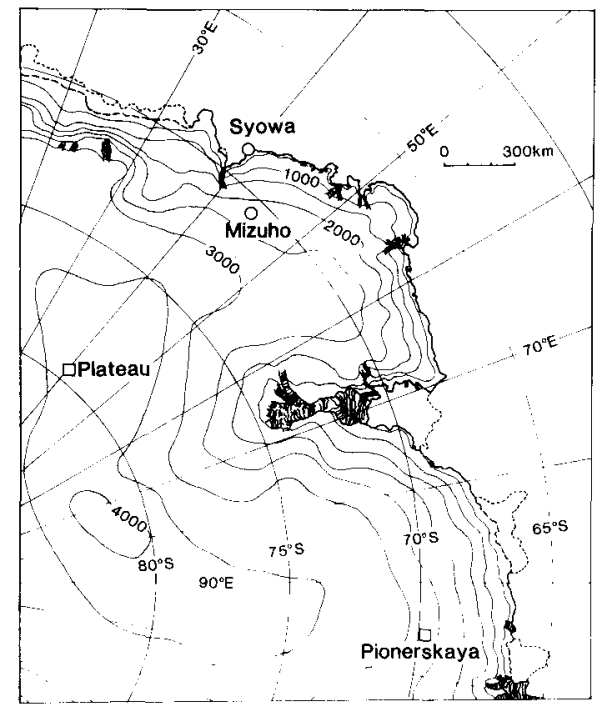

Fig.1. Location of Mizuho station.

budget measurements made at Mizuho station in 1979. Mizuho station is located on an ice-covered slope. and its climatic condition is controlled by continuously blowing katabatic winds. Its radiative regime is quite different from that of Syowa station which is located on the coast and from that of Plateau station which is inland. The basic data of measurements of radiation components were published by Yamanouchi and others (1981[b]) and micro-meteorological data were pub1 1 shed by Wada and others (1981).

\section{MEASUREMENTS OF RADIATION}

Pyranometers and pyrgeometers were used to measure four components of radiation fluxes: global and reflected short-wave and downward and upward longwave radiation. Measurements were made at the height of $1.5 \mathrm{~m}$ above the snow surface, and at the top of the $30 \mathrm{~m}$ tower. However, the results of the present paper were all obtained from ground measurements. Direct radiation was measured by a pyrheliometer, also at $1.5 \mathrm{~m}$. The spectral measurements of shortwave radiation divided in four wavelength intervals were carried out with cut-off filters. The output signals of radiometers were amplified and digitized, and digital data were sampled every minute and recorded on computer compatible magnetic tapes. The measuring and recording system is shown in Figure 2 . 


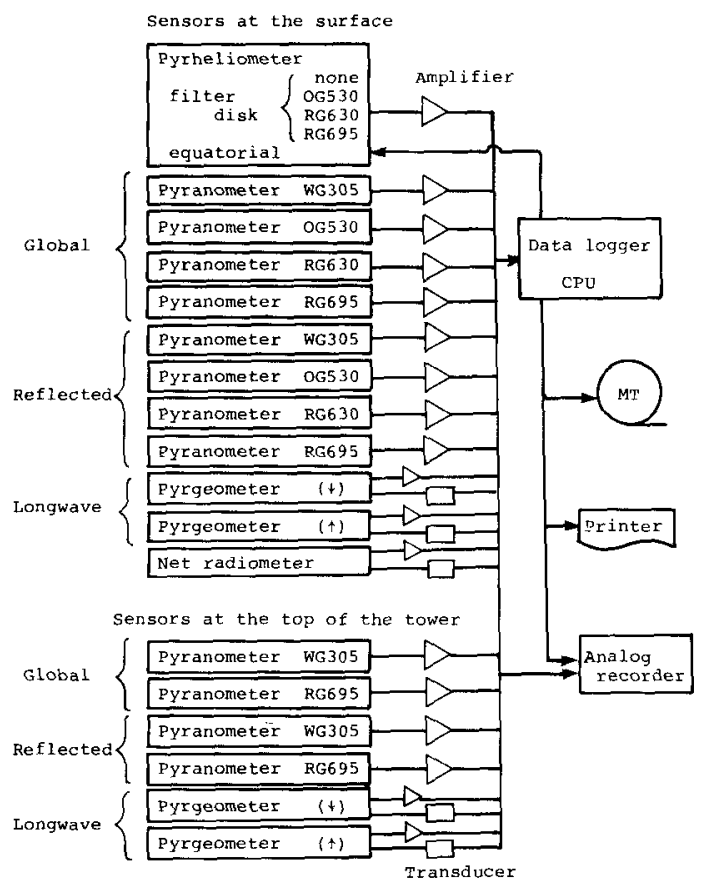

Fig.2. Measurement and recording system of radiation.

Pyranometers (MS-800) manufactured by Eko Instruments Co., Japan, were used to measure the global and reflected short-wave radiation. The short-wave fluxes discussed in the present paper were measured with pyranometers with a Schott's filter of WG 305 $(305-2800 \mathrm{~nm})$. To correct the deviation of the sensitivity constant from the cosine law dependence on the zenith angle and the temperature dependence, extensive calibrations were carried out in the field at Mizuho station using the pyrheliometer (Eko, MS-52F) which was calibrated against the Angström absolute pyrineliometer of IPS-1956. Calibration factors of the isotropic diffuse radiation and anisotropic sky radiation were derived and the calibration factor for the actual sky with a broken cloud cover was proposed using the effective clear-sky index (1-(mean cloud cover $))$. Details of the calibrations, and derivation of data are described by Yamanouchi and others (1981[a], 1981[b]).

The Eppley precision infrared radiometer with a hemispherical dome of silicon was used as a pyrgeometer. Though this filter dome does not transmit the shortwave flux, a measurement error occurred on account of the temperature difference between the dome and sensor surface, which originated from the solar radiation heating the hemispherical dome. To eliminate the heating of the dome, the up-facing pyrgeometer was equipped with a chrome plate ring to shade the direct solar radiation. For the correction of the measured long-wave flux without the shading ring, an approximate relation was derived. Reliabi]ities of long-wave flux values obtained with these methods were discussed also by Yamanouchi and others (1981[a]).

A net radiometer was not used to derive the net flux, because precise calibration, which had to be made independently for solar and long-wave flux respectively, was very difficult. Then the net radiation $R_{n}$ was obtained from four components: global $S_{d}$, reflected shortwave $S_{u}$, downward long-wave $L_{d}$ and upward long-wave $L_{u}$, as follows:

$$
\begin{aligned}
R_{n} & =S_{n}+L_{n} \\
& =S_{d}-S_{u}+L_{d}-L_{u},
\end{aligned}
$$

where $S_{n}$ and $L_{n}$ were net short-wave and net long-wave radiation respectively. The uncertainties of net radiation were $\pm 0.6 \mathrm{MJ} \mathrm{m}^{-2} \mathrm{~d}^{-1}$ for daily values and $\pm 18 \mathrm{MJ} \mathrm{m}^{-2}$ month $^{-1}$ for monthly totals.

3. PROPERTIES OF RADIATION BUDGETS OF MIZUHO STATION Daily variations of net radiation and meteorological parameters for June (winter) and December (summer) are shown in Figures 3 and 4 respectively. Net radiation for clear days was about $-3.5 \mathrm{MJ} \mathrm{m}^{-2} \mathrm{~d}^{-1}$ $\left(-801 \mathrm{y} \mathrm{d}^{-1}\right)$ in June and about $-0.5 \mathrm{MJ} \mathrm{m}^{-2} \mathrm{~d}^{-1}$ $\left(-10\right.$ ly $\left.d^{-1}\right)$ in December. It should be noted that the net radiation was al so negative in summer for clear days.

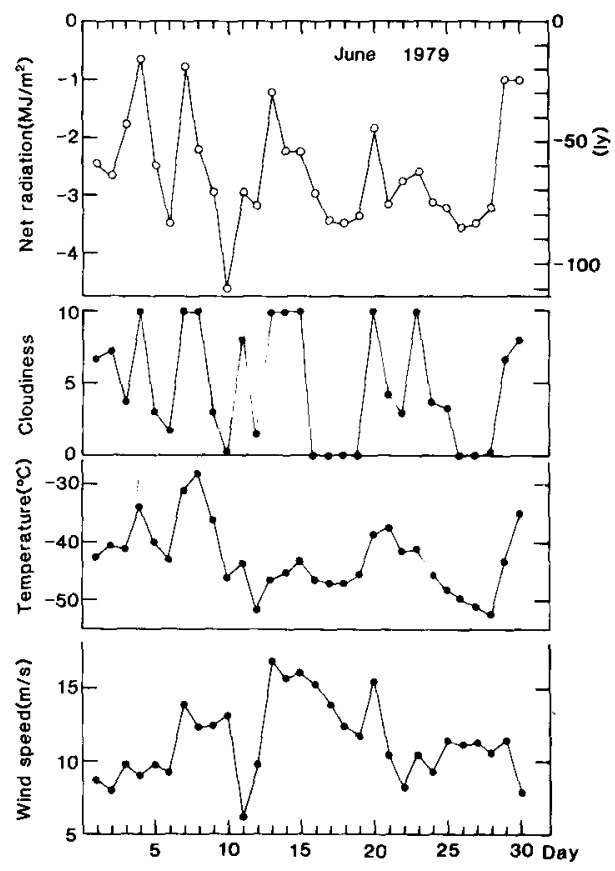

Fig.3. Daily totals of net radiation and daily mean values of meteorological elements at Mizuho station, June 1979 (Wada and others 1980).
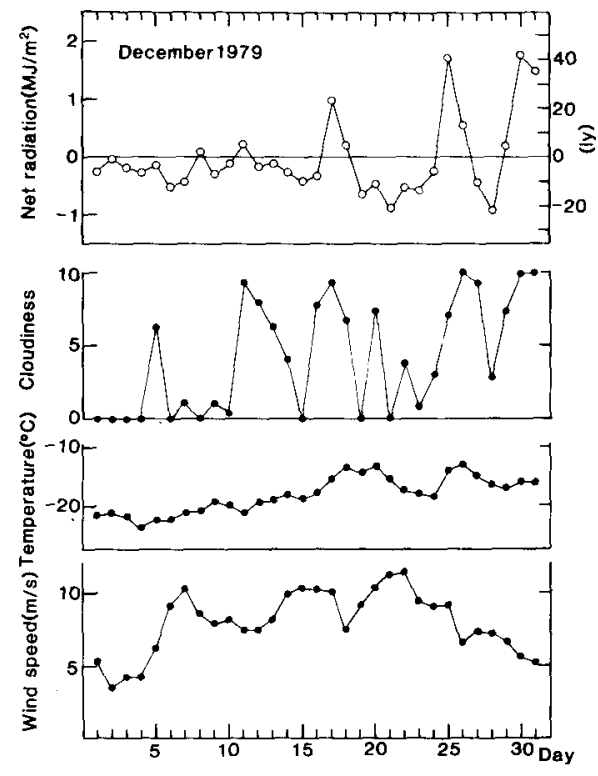

Fig.4. As Figure 3 but for December 1979. 
Day-to-day variation in June is due solely to net long-wave radiation and amounts to more than $2 \mathrm{WJ} \mathrm{m}^{-2}$. The variation of net radiation depends mainly on the amount of cloud, and the cloud shifts the radiation budget towards the positive direction. The effects of daily mean temperature or mean wind speed were not as obvious as the effects of cloud. Day-to-day variation in December (Fig.4) is smaller than that in June; however, the tendency of the changes caused by cloud is the same as in June.

Correlation coefficients between net radiation and meteorological parameters (for June and December) are listed in Table I. Table I indicates that the correlation between amount of cloud and net radiation

TABLE I. CORRELATION COEFFICIENTS BETWEEN DAILY AMOUNTS OF NET RADIATION AND METEOROLOGICAL ELEMENTS

Cloud amount Temperature Wind speed

$\begin{array}{llll}\text { June } & 0.77 & 0.59 & 0.07 \\ \text { December } & 0.59 & 0.28 & -0.32\end{array}$

in December is not as significant as in June, however, it is still higher than the correlation with temperature and wind speed. High correlations between net radiation and amount of cloud may firstly be attributable to the high albedo of the snow surface. Heating or cooling effects of cloud also depend on the properties of the cloud, namely, transmissivity of shortwave radiation and emissivity of long-wave; however, in the present case, only the heating effect of the cloud was observed. In the area of low albedo, cloud usually results in cooling on account of the large decrease in net short-wave radiation.

Seasonal variations of global radiation and downward long-wave radiation are shown in Figure 5 . In this figure, daily total values are plotted for two sky conditions: clear (cloud amount $0 / 10$ ) and overcast (only for middle and low cloud, cloud amount 10/10), and intermediate sky conditions are excluded. Global radiation for clear days changes monotonically from zero in winter to the maximum of $38 \mathrm{MJ} \mathrm{m} \mathrm{m}^{-2} \mathrm{~d}^{-1}$ (910 ly $\mathrm{d}^{-1}$ ) in summer and the scatter is small. Global radiation for cloudy (overcast) days is about 20 to $30 \%$ smaller than that for clear days. This rather small reduction of global radiation by cloud is due to the multiple reflections between the cloud and snow surfaces.

Seasonal variations of downward long-wave radiation for clear skies are about $5 \mathrm{MJ} \mathrm{m}^{-2} \mathrm{~d}^{-1}$ and considerable short-range day-to-day variations (scattering of points) are seen. This scatter may be due to the synoptic variations of atmospheric temperature and constituents such as water vapour and aerosols, and also may be due to the variations in amount of drifting snow. The downward long-wave radiation for cloudy days is about 7 to $8 \mathrm{~mJ} \mathrm{~m}^{-2}$, larger than

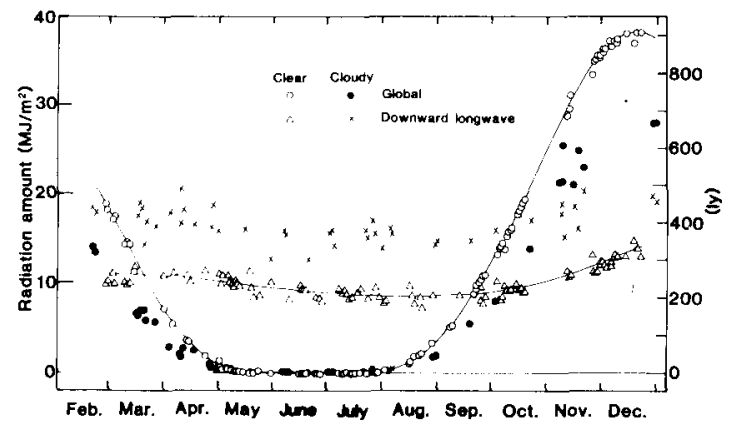

Fig.5. Daily totals of global and downward long-wave radiation for clear and overcast sky at Mizuho station, 1979. that for clear days throughout the year. Consequently, downward long-wave radiation was much more sensitive than global radiation to the amount of cloud and thereby controlled the daily variations of the net balance on many days throughout the year, though there were still other contributions to the variation from upward short-wave and long-wave radiation changes.

Seasonal variations of monthly totals of net radiation are shown in Figure 6 . In this figure, three Antarctic stations are included in addition to Mizuho station to make a comparison of the radiation budgets; however, in the present section, discussions are restricted only to the net radiation at Mizuho station. In the winter months from May to August, net radiation was nearly constant around

$-80 \mathrm{MJ} \mathrm{m}^{-2}$ month $^{-1}\left(-2 \mathrm{kly}\right.$ month $\left.^{-1}\right)$. These constant values are explained by small (sometimes zero) values of net short-wave radiation and are related to the "coreless winter" in regard to temperature. In summer, net radiation remained negative even for December in 1979. It is a striking result that at Mizuho station, net radiation in summer remains quite small. Whether the net radiation becomes negative or positive may largely depend on the occurrence of clear or cloudy days.

4. COMPARISON OF RADIATION BUDGETS AT ANTARCTIC STATIONS WITH DIFFERENT CLIMATIC CONDITIONS

To compare the radiation budget of Antarctic stations, three other stations besides Mizuho station are included in Figure 6 . According to the climatolo-

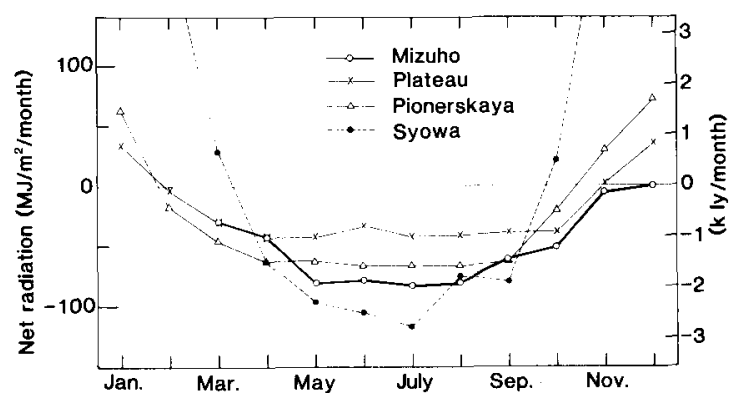

Fig.6. Monthiy totals of net radiation at four Antarctic stations, Mizuho (1979), Plateau

(1967, after Kuhn and others (1977)), Pionerskaya (1956-1958, after Rusin (1964)) and Syowa

(1967-1968, after Kawaguchi (1979)).

gical classification of Dalrymple (1966), Mizuho station is located in the "cold katabatic" region. Plateau station $\left(79^{\circ} 15^{\prime} \mathrm{S}, 40^{\circ} 30^{\prime} \mathrm{E}, 3630 \mathrm{~m}\right.$ a.s.1.) is in the "cold central core" which is characterized by low temperatures $\left(-56^{\circ} \mathrm{C}\right.$ in average) and relatively weak winds. Radiation data of this station measured in 1967 were taken from Kuhn and others (1977). Pionerskaya station $\left(69^{\circ} 44^{\prime} \mathrm{S}, 95^{\circ} 30^{\prime} \mathrm{E}, 2700 \mathrm{~m}\right.$ a.s. 1.$)$ is located on the glacial slope and is classified in the "cold katabatic" climate region, the same as Mizuho station. Radiation data for Pionerskaya were taken from Rusin (1964), who had obtained the data from an empirical relation which had been developed from results measured during the IGY between 1956 and 1958. Syowa station, which is the mother station to Mizuho, is located on East Ongul Island on the coast, where snow cover on the bare rock disappears in summer. Radiation data for this station which were the averages of the data measured in 1967 and 1968 were taken from Kawaguchi (1979).

In winter months, the amounts of net radiation for the four stations are in line with the heights of the stations or average air temperatures. The highest station, Plateau, shows the smallest negative value of about $-40 \mathrm{MJ} \mathrm{m}^{-2}$ month $^{-1}(-1 \mathrm{kly}$ month -1$)$, and and the lowest station, Syowa, shows the largest 
negative value of about $-120 \mathrm{mu} \mathrm{m} \mathrm{m}^{-2}$ month-1 $^{-1}$

$(-2.8$ kly month-1). This relation between net radiation and the altitude of the station was also reported by Rusin (1964).

In summer, the net radiation at Syowa station shows an extremely large positive value of about $400 \mathrm{MJ} \mathrm{m}^{-2}$ month $^{-1}$ (10 kly month $\mathrm{kn}^{-1}$ ), which clearly reflects the large amount of net short-wave radiation. At Syowa station, the snow cover disappears in the summer and the surface albedo decreases. At other stations, cold snow cover with high albedo still exists in summer; thus the monthly amounts of net radiation remain small. At Mizuho station, monthly amounts of net radiation between October and December were extremely small (negative) in contrast to those of the other stations (positive). If the relationship in winter months holds in the summer months, the values at Mizuho should be in between those of Syowa and Pionerskaya. Observations of radiation at Mizuho station were started on 18 February 1979, and the present discussion is based on 10 months in 1979. Monthly amounts of net radiation may differ from year-to-year, and the negative or positive values in summer months, in particular in December, may be only a chance occurrence as was mentioned in the previous section. However, in any case, it is apparent that the summer values at Mizuho are extremely small.

To examine these differences in detail, a comparison of other radiation components at the four stations was made. In Figure 7 , monthly amounts of net short-wave (effective short-wave) radiation are

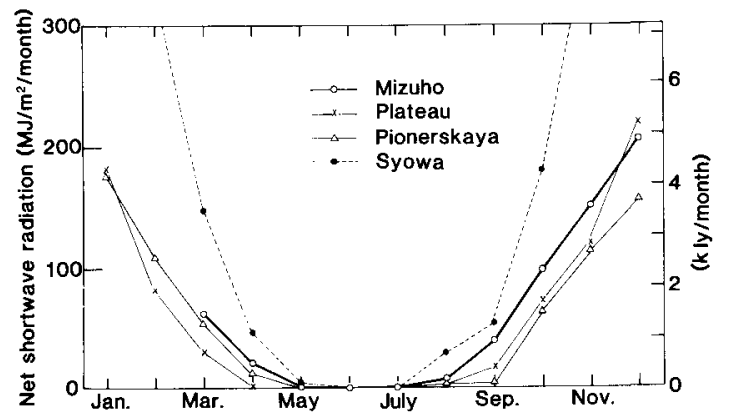

Fig.7. Monthly totals of net short-wave radiation at four Antarctic stations. Data source: same as Figure 6.

illustrated. Net short-wave radiation at Syowa station is extremely large in summer months, as was explained by the disappearance of the snow cover. Monthly amounts of net short-wave radiation at Mizuho are the second highest of these stations except in December. Monthly amounts at Plateau are the smallest froin February to April and those at Pionerskaya are the smallest from September to January. In general, there is not much difference in summer months between the inland stations.

In Figure 8 , four components of the radiation budget, global, reflected and downward and upward long-wave radiation are shown for three inland stations. Surface albedo is also shown in the lower part of Figure 8. Minor differences in the net short-wave radiation among inland stations are associated with similar differences in the amounts of global and reflected solar radiation. The amount of global radiation is mainly dependent on latitude according to the solar elevation. However, cloud amount and atmospheric constituents such as water vapour, aerosols, and drifting snow particles may also contribute to the variation of global radiation which has a close relation to the synoptic conditions, and relatively small amounts at Pionerskaya in December may be due to these factors.

The similarity of reflected solar radiation suggests that the difference in albedo in the three stations is small, and it is also confirmed from

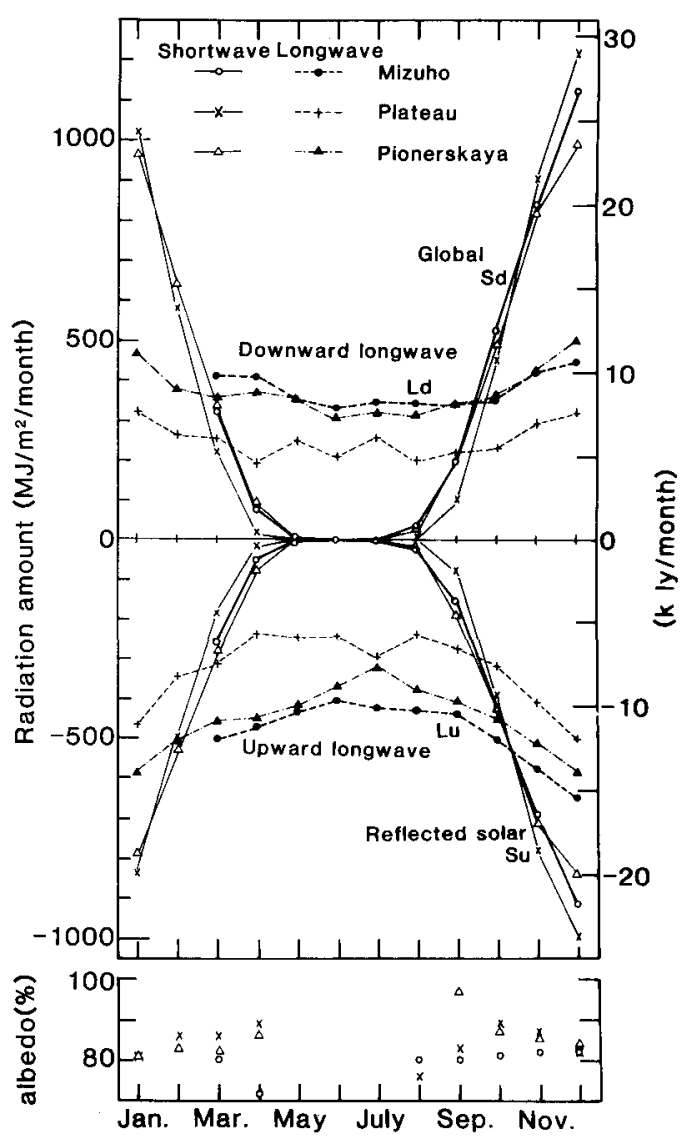

Fig.8. Monthly totals of global and reflected shortwave and downward and upward long-wave radiation, and mean albedo at three Antarctic stations. Data source: same as Figure 6 .

Figure 8. However, a further discussion will be given on the details of the surface albedo. Values of albedo at Mizuho station were obtained from the monthly totals of global and reflected radiation, being in the range between 80 and $82 \%$ except for April when there was uncertainty in the measurements of reflected radiation. The seasonal variation of albedo at Mizuho station is not remarkable, because the variation depends on the solar elevation and is also influenced by the variation of the surface conditions. Values of 80 to $82 \%$ at Mizuho are the lowest values for the inland stations reported by Rusin (1964) and Kuhn and others (1977). Kuhn and others explained that the low albedo at inland stations was due to the snow-surface erosion by strong winds. The difference in albedo between Mizuho and plateau stations is attributed to the difference in wind speeds, which supports the above explanation. However, the small difference in wind speeds at Mizuho and Pionerskaya may not explain their differences in albedo.

Figure 9 shows monthly amounts of net long-wave radiation at Mizuho, Plateau, Pionerskaya, and Syowa. Syowa station has the largest negative net long-wave radiation almost throughout the year, particularly in winter with about -100 to $-120 \mathrm{~mJ} \mathrm{~m}^{-2}$ month $-1(-2.2$ to -2.4 kly month-1). Mizuho station has the second largest values from May to October and the largest in December $\left(-210 \mathrm{MJ} \mathrm{m}^{-2}\right.$ month $\left.^{-1}\right)$. Plateau station has the smallest negative values from February to September (about $-40 \mathrm{MJ} \mathrm{m}^{-2}$ month-1 in winter) and the monthly values vary almost parallel to those at Mizuho.

Differences in monthly amounts of net long-wave radiation among Mizuho, Plateau, and also in the 


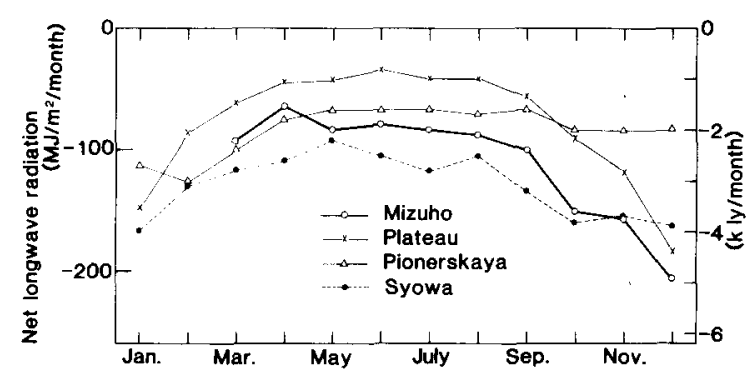

Fig.9. Monthly totals of net long-wave radiation at four Antarctic stations. Data source: same as Figure 6.

winter months at Pionerskaya are due mainly to the differences in upward long-wave radiation among these stations, depending on their surface temperatures. As shown in $F$ igure 8 , the large differences in upward long-wave radiation compared to the differences in the downward long-wave radiation among these stations occurs, which leads to the differences in the net long-wave radiation.

Upward long-wave radiation is prescribed by a temperature, and the temperature is also related to the degree of surface inversion. On account of radiation cooling, a strong inversion in the surface layer develops at inland stations. However, strong katabatic winds prevent the development of intense inversions. In Figure 10, monthly values of meteorological elements are shown. Comparing the wind speeds at the three stations, the difference in the strength of the surface inversion is apparent between Plateau and the other two stations, Mizuho and Pionerskaya.

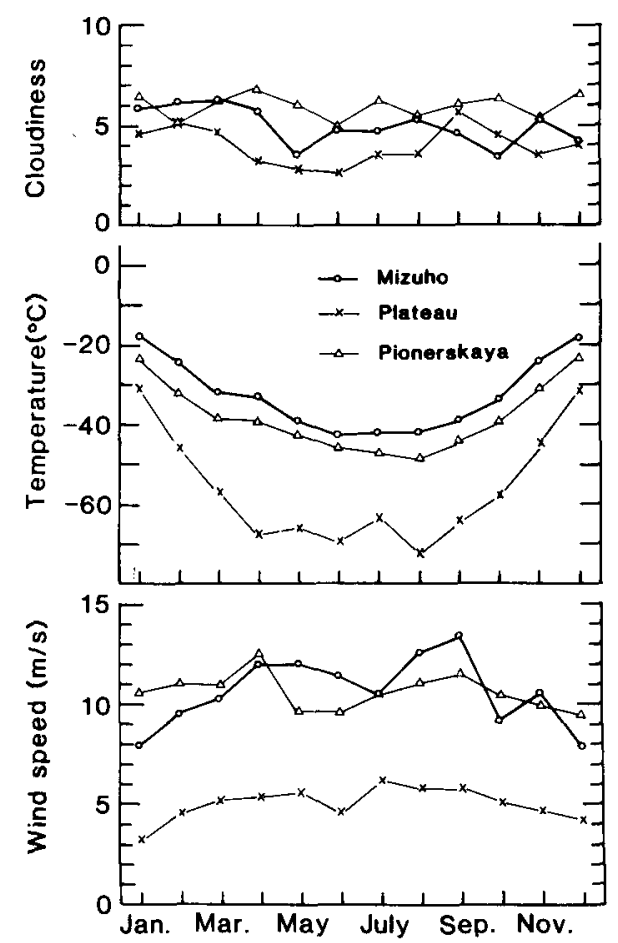

Fig.10. Monthly average of cloudiness, temperature, and wind speed at three Antarctic stations.

The seasonal trend of monthly amounts of net longwave radiation at Pionerskaya differs from that at Mizuho and Plateau (Fig.9). In November and December, the net long-wave radiation at $P$ ionerskaya is about $-80 \mathrm{MJ} \mathrm{m}^{-2}$ month $-1(-2 \mathrm{kly}$ month-1), which is nearly half of that at Mizuho and Plateau. Rusin (1964) attributed this small summer net long-wave radiation to the increase of atmospheric radiation on account of formation of clouds and fogs in the surface air layer. Figure 8 shows that, though the upward longwave radiation at Pionerskaya is always smaller than that at Mizuho, the downward long-wave radiation at Pionerskaya becomes larger than that at Mizuho from September to December.

To assess the condition of the atmospheric layer above the surface, the Angström ratio $\mathrm{A}_{0}$, $\mathrm{i}$.e.

$$
A_{0}=-\frac{L_{n}}{L_{u}}=1-\frac{L_{d}}{L_{u}},
$$

was introduced and is plotted in Figure 11. From the seasonal trend of $A_{0}$ shown in this figure, low values at Pionerskaya, compared to those at Mizuho and Plateau, are seen in summer. The sky condition at Mizuho is similar to that at Plateau. At these two stations, $A_{0}$ in spring is larger than in autumn.

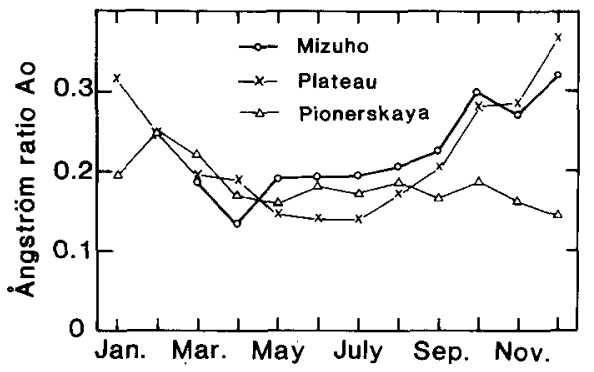

Fig.11. Monthly values of the Angström ratio for three Antarctic stations.

Clear atmospheric conditions in spring, which were observed by Kuhn and others (1977) for Plateau, may also exist at Mizuho. From the seasonal trend of $A_{0}$, Pionerskaya station seems to belong the coasta? climatic zone, though the distance from the coast is about $400 \mathrm{~km}$ which is greater than that of Mizuho $(250 \mathrm{~km})$.

From the foregoing discussion, the net long-wave radiation inland varies both with locality and season, whereas the net short-wave radiation varies relatively little with locality, which accounts for the varieties of total radiation balance at inland stations.

\section{CONCLUSIONS}

Characteristic features of the radiation balance at Mizuho station were as follows: (1) monthly amounts of radiation loss (negative) are very large (about $80 \mathrm{~kJ} \mathrm{~m} \mathrm{~m}^{-2}$ month-1 in winter) and even in summer the amount does not greatly exceed zero, (2) the influence of clouds on the daily radiation balance is prominent through long-wave radiation, shifting the radiation balance to the positive direction.

In comparing the radiation balance and ineteorological elements of several Antarctic stations, the dominant causes of the radiation climate at Mizuho station were identified as follows. Besides the high albedo of the snow cover, the surface temperature, which is affected by the constantly blowing katabatic wind, was one of the main factors in the radiation balance. The condition of the sky such as the cloudiness and the atmospheric constituents, was a further factor as was indicated clearly by the Angström ratio.

The distinctive climatic features of the radiation budget at interior stations were determined mainly by the characteristics of the long-wave radiation.

\section{ACKNOWLEDGEMENTS}

The authors wish to express their sincere thanks to the members of the wintering party of JARE-20 led by $\mathrm{Mr} M$ Yamazaki, Japan Meteorological Agency, for their support to the observations. Special thanks are due to Professor M Tanaka, Tohoku University, for planning the investigation. 
Dalrymple P C 1966 A physical climatology of the Antarctic plateau. In Rubin M J (ed) Studies in Antarctic meteorology. Washington, DC, American Geophysical Union: 195-231 (Antarctic Research Series 9)

Kawaguchi S 1979 Nankyoku no kisho [Antarctic meteorology]. Tenki 26(6): 335-346

Kuhn $M$, Kundla $L$ S, Stroschein L A 1977 The radiation budget at Plateau station, Antarctica, 1966-1967. In Businger J A (ed) Meteorological studies at Plateau station, Antaretica. Washington, DC, American Geophysical Union: 41-73 (Antarctic Research Series 25)

Kusunoki K 1981 Japanese polar experiment (POLEX)

in the Antarctic in 1978-1982. Memoirs of National Institute of Polar Research. Special Issue 19: 1-7

Mae S, Wada M, Yamanouchi T 1981 The system of measurements of radiation and micrometeorological elements at Mizuho station, East Antarctica: installation and performance. Antaretic Record 71: 44-57

Rusin N P 1964 Meteorological and radiational regime of Antarctica. Jerusalem, I srael Program for Scientific Translations (Translation of: Meteorologicheskiy $i$ radiatsionnyy rezhim Antarktidy. Leningrad, Gidrometeorologicheskoye Izdatel'stvo, 1961)

Wada M, Yamanouchi T, Mae S, Kawaguchi S 1980 Meteorological data at Mizuho station, Antarctica in 1979. Japanese Antarctic Research Expedition. JARE Data Reports 57

Wada $M$, Yamanouchi T, Mae S, Kawaguchi S, Kusunoki $K$ 1981 POLEX-South data, Part 2. Micrometeorological data at Mizuho station, Antarctica in 1979. Japanese Antarctic Research Expedition. JARE Data Reports 62

Yamanouchi $T$, Wada $M$, Mae $S$, Kawaguchi $S$, Tsukamura $K$ 1981[a] Measurements of radiation components at Mizuho station, East Antarctica in 1979. Memoins of National Institute of Polar Research. Special Issue 19: 27-39

Yamanouchi T, Wada M, Mae S, Kawaguchi S 1981[b] POLEX-South data, Part 1. Radiation data at Mizuho station, Antarctica in 1979. Japanese Antarctic Research Expedition. JARE Data Reports 61 